\title{
Estudo Histomorfométrico do Músculo Estriado de Ratas Castradas
}

Striated Muscle Histomorphometric Study of Rats in Anestrus

Autor: Manoel de Almeida Moreira

Orientador: Prof. Dr. Marcus Vinicius Henriques Brito

Dissertação de Mestrado em Motricidade Humana, apresentada ao Centro de Ciências Biológicas e da Saúde da Universidade do Estado do Pará, em 5 de março de 2004.

Objetivo: estudar alterações histomorfométricas do músculo estriado de ratas castradas.

Método: vinte e seis ratas (Rattus norvegicus albinus Rodentia, Mammalia), Wistar. A ovariectomia ocorreu no início do estudo, os animais foram, pesados, colhida citologia vaginal, biópsia do músculo rectus femoris, nas patas traseiras. Dividiu-se o total em dois subgrupos de 13 animais. No subgrupo A operou-se a pata direita e no B à esquerda; um grupo serviu de controle para o outro. Decorrido 20 dias, foi feita a segunda avaliação com citologia vaginal, documentando-se o estado de anestro. Após 70 dias, os animais foram pesados e submetidos à biópsia na pata traseira contralateral à primeira fase. A histomorfometria foi realizada, utilizando-se uma lente auxiliar com gradícula de $1 \mathrm{~cm}^{2}$ subdividida em quadradíclos de $1 \mathrm{~mm}^{2}$. Contou-se as miofibras, com seis leituras na vertical e cinco na horizontal, e obtendo-se um valor aplicado sobre uma fórmula que calcula o Coeficiente de Densidade Muscular.

Resultados: nos subgrupos a densidade muscular variou: em A de 60,0 para 52,3 (p<0,05), com variação de $14,1 \%$ para menor, e em B de 73,5 para 54,0 (p < 0,05), com variação de $26,5 \%$ para menor.

Conclusão: A castração provocou sarcopenia no músculo estriado de ratas castradas e redução do número de miofibrilas.

Palavras-chave: Hipoestrogenismo. Castração. Músculo estriado. Sarcopenia.

\section{CONCURSO SEXOLOG|A PERÍODO PARA ENVIO DO CURRÍCULUM:
15/04/2004 A 14/06/2004}

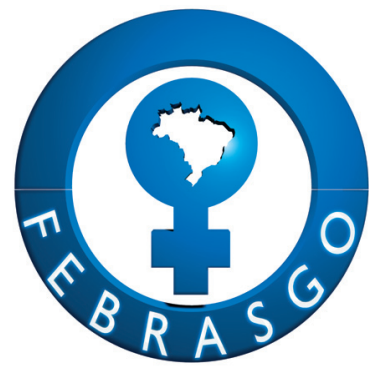

\author{
EDITAL E FICHA DE INSCRIÇÃO: \\ Retirar na Home Page da FEBRASGO \\ www.febrasgo.org.br
}

ENVIAR PARA SECRETARIA EXECUTIVA DA FEBRASGO:

Av. das Américas, 8445 - sala 711

Barra da Tijuca - Rio de Janeiro - RJ

22793-081

Tel.: (0xx21) 2487-6336 